\title{
Construction of the Evaluation System about Dual-tutor System for College Students based on the Whole Staff Education
}

\author{
X.D. YUAN* \\ Materials Science and Engineering Institute of Shandong Jianzhu University, Shandong Jinan 250101, China \\ G. ZHAO \\ Dean's Office of Shandong Special Education School, Shandong Jinan 250022, China
}

Y.T. ZHANG

Shandong Product Quality Inspection Research Institute, Jinan 250100, China

\begin{abstract}
The Materials Science and Engineering Institute of Shandong Jianzhu University was taken as an example in this paper to change people's concept on dual-tutor system from the evaluation subject, contents, and process. Evaluation principles of personalization, innovation and consistency were insisted on and three-dimensional style evaluation method by self-evaluation, comprehensive assessment and expertise evaluation was adopted to construct a scientific and rational dual-tutorial evaluation system for college students. Practice has proved that construction of the evaluation system is more important to the work efficiency of the dual-tutor evaluation system for college students.
\end{abstract}

KEYWORD: dual-tutor system; college students; education; evaluation system

\section{INTRODUCTION}

Dual-tutor system is not only a reform on the talent cultivation mode of undergraduate under the background of educational reform, but also an exploration for talent cultivation mode. Students' quality has been improved significantly, students' outlook on life and values has become noble gradually, students' employability and scientific research capacity has been improved significantly, the combination of theory and practice has become more closely, and students' comprehensive quality has been improved greatly since Materials Science and Engineering of Shandong Jianzhu University implemented dual-tutor system in 2006. There are still some restraints and constraints in the system, although the effect of dual-tutor system is remarkable, resulting in the existence of randomness and limitations in dual-tutor system, and the purpose of training students comprehensively can't be really achieved. Therefore, the exploration for the dualtutor evaluation system is imperative and profound.

The so-called evaluation system is a judgmental activity to dual-tutor work comprehensively and scientifically, according to the students' training objective and post responsibility, which has been reported widely in literatures ${ }^{[1-5]}$. This paper changes people's concept on dual-tutor system from the evaluation subject, contents, and process. And it insists on the evaluation principles of personalization, innovation and consistency to construct a scientific and rational college students dual-tutorial evaluation system.

\section{THE TRANSFORMATION OF CONCEPT ON THE EVALUATION OF DUAL-TUTOR SYSTEM FOR COLLEGE STUDENTS}

\subsection{The multidimensional evaluation subject}

At present, in order to improve the cultivation quality of college students, domestic colleges and universities are exploring a variety of talent training mode on tutor system. In order to carry out the various tutor system effectively, the form of inspection and supervision of the Youth League and teaching management is often adopted to evaluate the quality of the work of the system. For the full implementation of the dual-tutor system, Materials Science and Engineering of Shandong Jianzhu University, explores for the evaluation system, considering the disagreement of the evaluation subject to establish multidimensional evaluation subject including 'students' evaluation, tutors' evaluation, counsellors' evaluation, teaching evaluation, comprehensive evaluation." Adopting this evaluation subject can evaluate the work efficiency scientifically, objectively and accurately. Such evaluation subject can be not only students of different majors, also be teachers from different 
majors. Such evaluation enables students to continue to pursue progress, makes tutors reflect, explore and innovate constantly, practically making the work of dual-tutor system done.

\subsection{The evaluation based on the perspective of students}

The most important part of the dual-tutor evaluation system is evaluation content. The evaluation content should be confirmed from the perspective of students. The dual-tutor evaluation system should pay more attention to students' employability, innovation ability, practice ability and communication skills. It should emphasize on evaluating students' learning conditions, living conditions, the formation of values, establishment of integrity, improvement of aesthetics, improvement of practical ability, sense of love view etc. At the same time, it should also evaluate tutors from the perspective of students.

The evaluation content based on the perspective of students should be considered from long-term perspective, and should be regulated dynamically and scientifically.

\subsection{The scientific and dynamic evaluation process}

The past dual-tutor system took place at the end of term or the terminal year. The effect produced by the evaluation process is ignored. Evaluation process and effect should be combined with organically and supervised dynamically. Expressing scientifically the complexity and innovation generated by the tutors' work process can help improve tutors' motivation to work, which can also inspire students' personality in their study and life, and maximize the era significance of the dual-tutor system. As a result, instructors not only can boldly bring good practice into work, but also can promote the tutors to develop broader thinking. Under this working environment, students can easily apply the "Time Element" incisively and vividly. Scientific and dynamic supervision evaluation process is conducive to implement the dual-tutor system smoothly, but also to ensure the implementation effect of the dual-tutor system.

\section{PRINCIPLES AND METHODS OF EVALUATION ON DUAL-TUTOR SYSTEM FOR COLLEGE STUDENTS}

\subsection{The principle of respecting the personalization}

As college students enter colleges with 90s, while the concept of evaluation is changed, the times consciousness of college students should also be reflected. The college students' individuality of the times should be more respected for. The evaluation index system should respect for student's personality, inspire students' personality of the times, and play the spirit of students' individuality on the premise of completely achieving the goal of training talents. The training effects of double tutorial system taking the principle of respecting for the personalization have two sides. For one thing, the direction of the training objectives can be seized on the whole. For another thing, the students' characteristics can be highlighted in carrying out the work; their enthusiasm participating in this evaluation is mobilized; and their comprehensive capacity is also improved greatly. The principle of respecting for the personalization is a necessary principle of evaluating dual-tutor system. And it's also an important guarantee to train students of all aspects development of morality, intelligence and physique.

\subsection{The principle of encouraging innovation}

Innovation is an inexhaustible motive force of all the work. The evaluation index system still adheres to the principle of encouraging innovation. Because the evaluation process becoming more complex, the effect of evaluation pursuing of objectives, the subject of evaluation gradually becoming diversified, furthermore the dual-tutor system itself a practical activity, so evaluation on college students dual-tutor system essentially needs innovative. Innovation can avoid the work of dual-tutor system from dispelling the enthusiasm of tutors and students because of formalization, simplification and old-fashion. It also ensures to improve continually all aspects of students' ability, and to cultivate the students' innovative spirit. The significance of dual-tutor system for students lies in improving their comprehensive quality, helping the development of their individualities and raising their innovation capabilities. Visibly, the innovation is an essential principle in evaluating the effect of dual-tutor system.

\subsection{The principle of consistency}

Because the evaluation of dual-tutor system itself a part of education, so it should follow educational goals, especially the goal of cultivating talent college students under the Education Reform in the "the national 12th Five-Year Plan". Dual-tutor system itself is also an innovation of mode of training talents under the Education Reform. Therefore, the subject or the content of the evaluation must comply with the principle of consistency. That is, they must keep to the goals of cultivating talent college students under the Education Reform. Following this goal, it's necessary to take the all-round improvement of students' comprehensive quality as whole situation, and constantly to pursue improvement of other skills. Following this target, 
it's important to make the cultivation of students' innovative spirit as a fundamental problem, and to serve student's education filled with personality. Following this aim, regard help students to establish a scientific value as our own duty to cultivate qualified successors for socialism.

\subsection{The three-dimensional evaluation method}

In order to make the evaluation of dual-tutor system objective, scientific and epochal, self-assessment, comprehensive evaluation and expert assessment are adopted to form evaluation of the three-dimensional type. Dual-tutor system is an individualized education system. While the personality of students is embodied, the instructors' views of their own should also be respected. By self-assessment to reflect the effectiveness and feasibility of dual-tutor system, tutors' will even more actively participate in implementing the dual-tutor system. Meanwhile, it's necessary to organize the appropriate experts, a comprehensive evaluation of different profession but peers and specialist evaluation. And the three kinds of approaches cross and complement mutually. And tutors' self-assessment accounts for $30 \%$, the comprehensive evaluation 40 percent and specialist evaluation $30 \%$.
4 CONSTRUCTION OF THE EVALUATION SYSTEM ABOUT DUAL-TUTOR SYSTEM FOR COLLEGE STUDENTS

The evaluation index system of dual-tutor system is the soul of the whole evaluation system. Its confirmation is directly related to the dual-tutor system's correctness, scientificity and feasibility. It must regard the educational thought in "the national 12th Five-Year Plan" as the guiding ideology, always adhering to Scientific Outlook on Development; taking the code of cultivating talent college students in "the national 12th Five-Year Plan" as the goal; making the pratical work of scientific tutors in the new times as platform, inspecting tutors' all work roundly and deeply, and understanding students' transmutation of thought, learning situation, living conditions, emotional status, the ability of integrity etc in depth. At the same time, the evaluation index system should embody effectivity, simplicity and scientificity to the best of its abilities. The constructure of evaluation index system mainly includes five-level indicators, twelve major fixed points, and four grade standards, together with the reference weights shown in Table1. Many studies have been done on such items [6-10].

Table1 The evaluation index system of dual-tutor system fro college students

\begin{tabular}{|c|c|c|c|c|}
\hline \multirow{2}{*}{$\begin{array}{l}\text { First level in } \\
\text { dicators }\end{array}$} & \multirow{2}{*}{$\begin{array}{l}\text { Major fixed } \\
\text { points }\end{array}$} & \multirow{2}{*}{$\begin{array}{l}\text { Reference } \\
\text { weights }\end{array}$} & \multicolumn{2}{|l|}{ Grade standard } \\
\hline & & & A & $\mathrm{C}$ \\
\hline $\begin{array}{l}\text { job } \\
\text { responsibilities } \\
\text { ( } 20 \text { points) }\end{array}$ & $\begin{array}{l}\bullet \text { thinking } \\
\text { ituations } \\
\bullet \text { life }\end{array}$ & $\begin{array}{l}0.4 \\
0.6\end{array}$ & $\begin{array}{l}\text {-care about students; a noble } \\
\text { morality; serve as role models } \\
\text { - solve all kinds of the difficulties } \\
\text { in students life }\end{array}$ & $\begin{array}{l}\text { - ordinary students' health and values } \\
\text { - care about students various difficulties } \\
\text { basically }\end{array}$ \\
\hline $\begin{array}{l}\text { work attitudes } \\
\text { and methods } \\
\text { ( } 20 \text { points) }\end{array}$ & -attitudes & 0.5 & $\begin{array}{l}\text {-rigorous scholarship; serve as role } \\
\text { models; have an active role in the } \\
\text { formation of values } \\
\text {-work include recording, planning, } \\
\text { summarizing, innovating, holding } \\
\text { students seminars, communicating, } \\
\text { listening to students' opinions }\end{array}$ & $\begin{array}{l}\text {-work actively; } \\
\text { serious attitude; affect students' } \\
\text { enthusiasm from their thought } \\
\text { - arrange for and carry out works } \\
\text { according to unification; better } \\
\text { comprehensive plan and summary; } \\
\text { carry out a students' seminar per month, } \\
\text { with record and summary }\end{array}$ \\
\hline $\begin{array}{l}\text { work } \\
\text { efficiency } \\
\text { ( } 30 \text { points) }\end{array}$ & $\begin{array}{l}\text { •students } \\
\text { quality } \\
\text { •employability }\end{array}$ & $\begin{array}{l}0.4 \\
0.6\end{array}$ & $\begin{array}{l}\text {-a healthy personality; noble values; } \\
\text { an outstanding ability } \\
\text {-to plan science; excellent } \\
\text { interpersonal communication and } \\
\text { expertise }\end{array}$ & $\begin{array}{l}\text { - no fighting; respect for teachers; unite } \\
\text { students } \\
\text {-a better capability of collaboration; a } \\
\text { strong ability to communicate with } \\
\text { students }\end{array}$ \\
\hline $\begin{array}{l}\text { Work } \\
\text { innovation } \\
\text { ( } 30 \text { points) }\end{array}$ & $\begin{array}{l}\bullet \text { methods } \\
\text { innovation } \\
\text { •thinking } \\
\text { innovation }\end{array}$ & $\begin{array}{l}0.5 \\
0.5\end{array}$ & $\begin{array}{l}\text {-to work from the perspective of } \\
\text { students; scientific method } \\
\text { - the thought of work reflects the } \\
\text { needs of students; high students } \\
\text { evaluation; reflect well }\end{array}$ & $\begin{array}{l}\text {-the working methods are suitable for } \\
\text { students to develop by right way } \\
\text { basically } \\
\text { •innovate the work thinking according to } \\
\text { the students' needs; good students } \\
\text { evaluation; common reflection }\end{array}$ \\
\hline
\end{tabular}

[Note]: 1. Conclusions of evaluation are classified into excellent, good, qualified, and unqualified grades, including: $A \geq 18, B \geq 15, C \geq 12, D<12$.

2. The criteria for this scheme are given by A and C. B is between A and C. D is lower than C. 


\section{CONCLUSIONS}

The dual-tutor system adopts three-dimensional style evaluation method by combining self-evaluation, comprehensive assessment and expertise evaluation, to construct a scientific and rational dual-tutorial evaluation system for college students. Practice has proved that it is very important to cultivate college students of all aspects.

\section{REFERENCES}

[1] Junqing Zhou, Shujie Wen. The reflection and exploration about constructing evaluation system of undergraduate dual-tutor system. The textile economy of Shandong, 2009(5):136-137.

[2] Jing An. The research on evaluation system based on the work of undergraduates' tutor assessment of high school with credit system. 2009(1):135.

[3] Liyan Liang, Yixiong Luo, Yaodong Wei. etc. Perfect the evaluation system of undergraduate tutor system and to promote the rapid development of national medical education. The theory and practice of education, 2010 (18):643-645.
[4] Lin Chang. The research on constructing the evaluation system of undergraduate tutor system as performance. The academic journal on Teachers College of Huaibei Coal, 2009 (30):152-156.

[5] Rui $\mathrm{Xu}$, Guohua Jin, The constructure and analysis on "flowing tutor system "of undergraduates in high school. Education and science, 2011 (27):54-57.

[6] Junqing Zhou, Shujie Wen, The constructure on carrying out evaluation index system of undergraduate tutor system of higher education based students perspective. The academic journal of Changchun Institute of Education, 2010 (26):10-12.

[7] Xue Yu, Zhiyong Xiong, Guizhen Chen, The build of evaluation index system on undergraduates resulting in performance.evaluation system. The guiding newspaper on science and technology innovation, 2010, 137-139.

[8] Qing Li, Optimization on implementing the mode of higher education undergraduate tutorial system. Practice and exploration, 2011, 241-243.

[9] Ling Zhang, Xiaoliang Yuan, The research on implementing the mode of higher education undergraduate tutorial system. The exploration on teaching and researching. 2008 (8):2036-2037.

[10] Shuhong $\mathrm{Xu}$, Shouzan Liu, The constructure on carrying out evaluation index system of undergraduate tutor system of higher education. Education in Heilong jiang.2010 (8):19-21. 